\title{
Virtual Learning Environments and Realizing Right to Education in COVID-19 Situation
}

\author{
Shazia Mansoori \\ Assistant Professor, Department of Education, Aligarh Muslim University, Aligarh, Uttar Pradesh, India \\ Corresponding author: shazia.ed@amu.ac.in
}

Received: 10 Feb., 2020

Revised: 13 Apr, 2020

Accepted: 27 May, 2020

\begin{abstract}
In the prevailing worldwide situation, the virtual learning environment has grown to be inseparable part of life. Covid19 has taken a grip of the globe, affecting every sector of the economy drastically. Education has also suffered a setback in the manner that all schools, colleges and universities have shut down due to the complete lockdown. However, social distancing, which is the new motto to stop the spread of the deadly virus, has created opportunities for virtual world. In addition to education, all other sectors of nation's development have also utilized the avenues of 'digitalisation'. Learning systems pertaining to school education, university education, etc. have also grown technologically. Teachers and students have refined their skills of virtual/ online learning to meet the educational needs. Be it a MOODLE course, or a class group meeting on video conference calls, or submitting assignments on Google Classroom, or taking online tests, or registration through google forms, or other numerous web tools, learning and associated formalities have become accessible and easier for all. The present article explores the prevalence, utility and challenges faced in the tremendous growth of virtual learning environments. The author has reviewed the scope of virtual learning and discussed the various practical ways by which learning remains unaffected, even in the present crisis of COVID- 19.
\end{abstract}

Keywords: Virtual learning, Virtual Environments, Online teaching, COVID-19, Pandemic

Education is a right. The duty of the education provider is to make it an offer at ease. During COVID-19 pandemic, education providers have been stretched too far by the situation to continue teaching-learning ecosystem. So, institutions have been shifting in big way to virtual classrooms.

Virtual environments refer to the network of online activities conducted through the use of internet, computer or any other digital device. The learning takes place not only outside the four walls of educational institutions, but also bringing technology to the classrooms. A Virtual Learning Environment (VLE) is an accumulation of incorporated software components, empowering the administration of web-based learning (online learning, e-learning) (Laeeq and Memon, 2018). It is an online environment, as a way of connecting students, ease of access to learning resources, not bounded by time and space, and helping in teacher's professional learning and development. The demand of online learning is not something recent, it has grown exponentially over years. The necessity of virtual learning systems has increased but it requires that the educational environments

How to cite this article: Mansoori, S. (2020). Virtual Learning Environments and Realizing Right to Education in COVID-19 Situation. Int. J. Peace, Edu. and Deve., 8(01): 33-39.

Source of Support: None; Conflict of Interest: None 
which are built thereof should be more flexible and accessible. Terms like online learning, Internet-based learning, web-based learning and e-learning are used interchangeably by practitioners in the field (Capper, 2001). Use of social networking sites in the learning process have found to positively influence academic performance of students (Mansoori and Shorif, 2019). Accessibility of computers and internet technology is the priority to engage in virtual environments. The success of learning systems depends on meeting the needs of the learners. Is it flexible? Does it have improved design, and ease of control/ usage? What additional features like chats, forums, discussion boards, etc. does it offer? The answer to these few questions will direct us to a number of virtual learning applications and systems which cater to the ongoing need of teaching and learning, both for teachers and learners.

However, with the advent of virtual learning and its' successful implementation in many educational institutions, the skills required to design, implement and use them, are essential. These technological skills can be gained with appropriate training and support. A substantial amount of investment, resources, and time is needed. Any virtual learning environment cannot be created without the active participation of experts in the field, educators, and learners. Information is not just shared and received but also generated according to the requirements. 'Not only do we need to learn how to teach differently, but we need to help our students to learn differently' (Kelly and Roberts, 2000). Collaboration is another essential feature of virtual learning environments. Social skills are highly improved and students' interaction on such platforms, enhances the learning process. Carfeul strategic planning is another step towards success of these learning systems. With so much credit to virtual learning, does it face challenges in our education system? How well- versed are we in coping with technological concerns of our population in terms of accessibilty? Do virtual learning environments show a bright future with respect to quality in teaching and learning? All these problems and questions will be encountered in the due course of using these learning systems. We have to prepare ourselves with new strategies to utilize these useful technologies, in times like today.

\section{Covid- 19: Worldwide lockdown!}

COVID-19 pandemic has created challenges in teaching and learning, leading to revolutionized changes in the educational settings. The spread of coronavirus around the world during late 2019 was never expected to take a toll on life and associated activities in such a short span of time. By March 2020, the worldwide spread of virus prompted governments to take strict action at the earliest. The outbreak was declared a global pandemic by the World Health Organization (WHO) on 11 March 2020. A pandemic is when an infectious disease is passing easily from person to person in many parts of the world at the same time. In India, the first complete lockdown started in late March 2020, and continued till June 2020 when some relaxations were allowed. However, the phased lockdowns still continue with intermittent relaxed phases. Coronavirus is continuing its spread across the world, with almost 16 million confirmed cases in 188 countries. More than 630,000 people have lost their lives (BBC News, 2020).

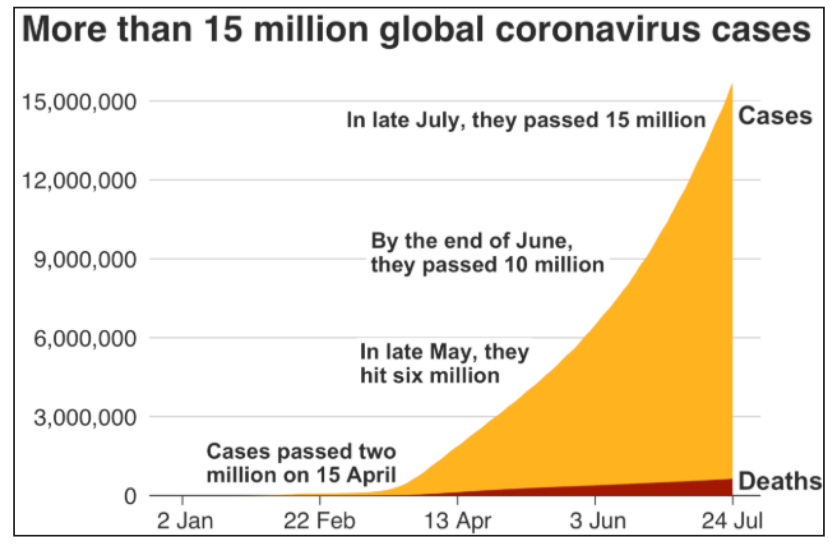

Source: Johns Hopkins University, National Health Agencies, data up to 24 July BBC

Fig. 1

Governments across the world have been forced to limit the movement of the public in a bid to slow the spread of the virus, which has had a devastating impact on the global economy. The International Monetary Fund has said the world is in the midst of 
Virtual Learning Environments and Realizing Right to Education in COVID-19 Situation

the worst recession since the Great Depression and warned that it could take two years for economic output to return to pre-pandemic levels (BBC News, 2020).

The lockdown greatly affected the education sector, with schools shutting down. Till date, the schools are closed. However, the education system rose to occasion in order to meet the demands of learners. A variety of learning systems and resources were created, shared and managed to take online/ live classes, conduct tests, submit assignments, and even provide professional training of teachers to use various teaching- learning softwares and applications. It's difficult to say how long the shutdown will continue. So there is no other choice with the teachers and students but to direct themselves towards the online learning systems.

It is the responsibility of the stakeholders of education to cater to the educational needs of the learners. Rapid innovations and changes using technology are welcome in the field of teaching- learning. The educational institutions have to harness the technology in ways to benefit the teachers as well as students. Communication and interactions are key to a successful learning system. Thus, creating content, using information from online resources, conducting examinations, dissemination of resources, etc. have began with the advent of this COVID-19 crisis.

UNESCO (2020) mentioned the adverse effects which COVID-19 lockdowns may have on schools and other educational institutions around the world. Not only learning is affected but the opportunities for youth's growth and development are inhibited. Therefore, successful combat of the prevailing situation in most effective manner can be accomplished only by means of launching such e- learning systems which benefit both the teachers and students. Web 2.0 technologies have seeped into the education system providing the learners immense control of their learning process and catering to their own learning styles and needs (Shakique and Mansoori, 2017). A large number of available information systems will help the educators to utilize the resources accordingly.

\section{Virtual learning environment (VLE)}

For online courses to be effective, appropriate training and technical support for teachers and learners is required, as they develop new strategies in response to new technologies for learning (Westbrook, 2006). Online learning systems employ a variety of online tools, systems, and software, which place new demands on the technical competence of instructors (Volery and Lord, 2000). Effective instructor-student communication in online learning environments relies on timely and clear interactions through a variety of formats (Easton, 2003). Studies have been conducted which reveal the adoption and utilization of technology in the recent times. A sudden surge of using online resources and learning mangement systems (LMS) have greatly facilitated the process of teaching and learning. In context of learning in the classrooms, technology adoption was found to be enriching and supportive for both teachers and learners. Demands for flexible learning is not something new, stakeholders of education system have continued to expand avenues for lifelong learning using technology. Teachers have found to benefit from online learning (Roblyer et al. 2010). Interactions also occur through a variety of methods, including learner-to-content, learner-to-instructor, and learner-to-learner (peer) interaction (Bolliger and Martindale, 2004). A strong relationship between the two variables namely students' perception of satisfaction in online courses and use of technology, has been found (Lee, 2010). Virtual learning environments (VLE) have recently emerged as an important topic in education theory and practice (Weller, 2007). The core functionality of any virtual learning environment includes (https://scand.com/company/blog/the-use-of-virtuallearning-environment-in-education/):

1. Planning and management of lessons and other activities;

2. Access to digital learning materials: texts, videos, images, podcasts, etc.;

3. Group discussions and one-on-one chats with a teacher; 
4. Submitting homework and other tasks;

5. Grading, tracking students' performance, providing feedback;

6. Holding live lessons.

Virtual learning environments (VLEs) help to cater to the learner's needs and learning styles accordingly. It makes the students, active participants of the instructional process. Effective VLEs provide content in different formats which enables good learning experiences to the students. A number of presentation styles are available. VLEs help in better collaboration of the learners, their engagement, assessment, administration, lesson planning, etc. These learning environments can be used as supportive systems in addition to the traditional classroom learning. However, in the present COVID-19 lockdown situation, educators have started to solely depend on such learning environments to keep the learning process going effectively. VLEs are centrally provided services that are delivered right across the institution largely to enhance existing academic practices, not to replace them. VLEs offer a vast array of functionality covering academic administration, teaching and research delivered by a wide range of software that has grown according to a broad spectrum of requirements (Trafford and Shirota, 2011). The functionality and competency of any VLE can be studied with respect to the content, ease and interactivity, support system and management interface which it provides. Most VLEs support the Shareable Content Object Reference Model (SCORM) as a standard, but there are no commonly used standards that define how the learner's performance within a course can be transferred from one VLE to another.

\section{Objective and Approach}

The present paper will discuss the distinctive features of virtual learning environments so that educators can better utilize them according to their requirements. Comparative studies of a few VLEs based on certain criteria have been conducted. Based on the features and capabilities of VLE tools, advantages of using these learning environments have been documented (Ajlan and Al-Ajlan, 2012).

\section{VL Products}

The researcher studied eleven VLE products to understand availability in the marketplace. Virtual learning environments incorporate supportive learners' tools, administration tools, course delivery tools, and content development tools. Each tool has certain defined characteristics which may differ in different VLEs. Examples of VLEs include MOODLE, Scholar 360, WebCT, First Class, Canvas, WebLearn, TeleTOP Virtual Learning Environment, The Blackboard Learning System, Desire2Learn, ANGEL Learning Management Suite, and Sakai. Each VLE has features which maybe overlapping or even unique for each. Any educational institution can develop/ home- design a VLE of its own for its learners, by hosting innovative and engaging resources in many subject areas. This is for the convenience of the teachers and students both.

\section{VL Environment \& Functions}

VL environments must include, among others, characteristics of centralization and automation of administrative procedures, use of services oriented to users, reduction and distribution of contents, consolidation of training initiatives, personalization of contents and reuse of knowledge (Ellis, 2009). These platforms provide space for storing and presenting content. Learners' tools to help manage communication and interaction of teachers and learners, and facilitation of the learning experience are also important aspects. VLEs provide platform for communication and ease of interactivity through additional tools/ features of blogs, forums, threaded discussions, messages, etc. Administration tools include student registration, tracking, and monitoring. Notice/ bulletin boards also represent administrative function. Course content management, flexibility in access of learning content, course materials, lecture notes, readings, recommended websites, and library resources are also available. Online assignments or assessments, including electronic submission of conventional essays and also facilitating projects, presentations and collaboratively authored webpages (McAvinia, 2016), using quiz, and other question 


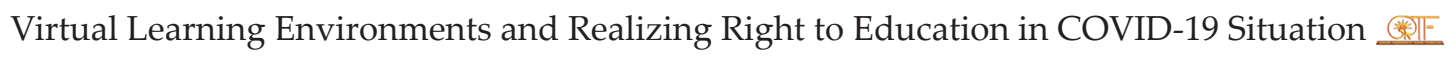

formats for grading and providing feedback to the learners also contribute to efficiency of VLE. Shared workplaces of VLE enhance collaboration among the users. A major component of a virtual learning environment is breaking the curriculum into sections that can be assigned and assessed, online support for both teacher and students (https://www. futurereadyedu.com/virtual-learning-environmentsvles/). Video presentations, podcasts, hyperlinks to external content can also be organised. VLES typically provide a set of options that determine who has access to these resources and also at what level (such as reading, commenting, editing and administering). This is a key feature that enables fine-grained control: areas can be made open (to members of the public) or closed, for instance limiting access to a particular group and making materials available only between certain dates (Trafford and Shirota, 2011). It is noteworthy here that no single VLE product can possibly meet all the criteria and may not be the best for interface, technical, functional, or cost reasons.

Summarizing the features of VLE tools, a comprehensive list is presented in the table 1 (Ajlan and Al-Ajlan, 2012).

\section{Let's cross the bridge!}

Determining the usage and significance of virtual learning environments was extensively explored in aforementioned paragraphs. The applications of the virtual learning environments in education system of any institution anywhere on the Earth is of immense importance in COVID-19 crisis. However, it's also important to note that appropriate training of teachers as well as students is required in order to effectively use these learning environments.

Table 1

\begin{tabular}{|c|c|c|}
\hline 1) Learner Tools & 2) Support Tools & 3) Technical Specifications \\
\hline $\begin{array}{l}\text { 1. Communication Tools } \\
\text { - Discussion Forums } \\
\text { - File Exchange / Internal } \\
\text { Email } \\
\text { - Online Journal/Notes } \\
\text { - Real-time Chat } \\
\text { - Video Services / Whiteboard }\end{array}$ & $\begin{array}{l}\text { 1. Administration Tools } \\
\text { - Authentication } \\
\text { - Course Authorization } \\
\text { - Registration Integration } \\
\text { - Hosted Services }\end{array}$ & $\begin{array}{l}\text { 1. Hardware/Software } \\
\text { - Client Browser Required } \\
\text { - Database Requirements } \\
\text { - Server Software } \\
\text { - UNIX Server } \\
\text { - Windows Server }\end{array}$ \\
\hline $\begin{array}{l}\text { 2. Productivity Tools } \\
\text { - Bookmarks } \\
\text { - Orientation / Help } \\
\text { - Searching Within Course } \\
\text { - Calendar / Progress Review } \\
\text { - Work Offline/Synchronize }\end{array}$ & $\begin{array}{l}\text { 2. Course Delivery Tools } \\
\text { - Course Management } \\
\text { - Instructor Helpdesk } \\
\text { - Online Grading Tools } \\
\text { - Student Tracking } \\
\text { - Automated Testing and Scoring }\end{array}$ & $\begin{array}{l}\text { 2. Pricing/Licensing } \\
\text { - Company Profile } \\
\text { - Costs } \\
\text { - Open Source } \\
\text { - Optional Extras } \\
\text { - Software Version }\end{array}$ \\
\hline $\begin{array}{l}\text { 3.Student Involvement Tools } \\
\text { - Groupwork } \\
\text { - Self-assessment } \\
\text { - Student Community } \\
\text { Building } \\
\text { - Student Portfolios }\end{array}$ & $\begin{array}{l}\text { 3. Curriculum Design } \\
\text { - Accessibility Compliance } \\
\text { - Course Templates } \\
\text { - Curriculum Management } \\
\text { - Customized Look and Feel } \\
\text { - Instructional Standards } \\
\text { Compliance } \\
\text { - Instructional Design Tools } \\
\text { - Content Sharing / Reuse }\end{array}$ & \\
\hline
\end{tabular}

Source: Ajlan S. Al-Ajlan (2012) 
Information and Communication Technology tools and skills are improving everyday, with e- resources being made open source and free. Online training programs are conducted, learners gaining new skills and achieving new levels of expertise. For improved performance and participation in learning process, VLE with associated tools and features can prove a boon. Given appropriate planning and preparation, virtual learning environments can contribute towards a more creative and productive educational experience. Virtual learning environments in the near future can be seen in the form of:

1. Virtual science laboratories where students can conduct experiments or observe phenomena.

2. Virtual humanities environments such as museums, archaeological sites, or historical time periods.

3. Virtual corporate training spaces where employees can train on new equipment, attend meetings, and peruse documents (BBC News, 2020 and UNESCO 2020).

Flexibility and accessibility to the learners in using the content according to their pace and time promises self-directed learning through VLEs. Creation of knowledge by teachers should therefore be suited to apply to these learning systems. So, online faculty professional development programs need to be arranged to create, communicate and share resources. The challenges faced by schools, colleges and universities require efforts to combat the obstacles in the path of learning due to COVID-19 pandemic. Increased interaction, collaboration and communication will help in dissemination of knowledge, getting guidance, building academic relationships, and enhancing the quality of teaching and learning.

\section{Challenges Galore}

It's important to point here that certain challenges were observed while using the VLEs both by teachers and students. Access to internet, ICT support and devices is still a far cry for majority of population. Apart from this, lack of technical skills, unwillingness to use/ implement these environments has weakened their adoption in education system.
Other issues like course content having less quality in terms of interactivity, misalignment of course content with learners' need, teachers resistance to technology- acceptance, lack of security and privacy concerns, etc. need to be addressed. But all these concerns can be done away once the teachers and learners support the usage and adoption of Virtual Learning Environments (VLEs). Highlighting the need of these environments, novel contributions through researches can be provided to educational institutions in order to review and renew the teaching and learning process during and also post COVID- 19 crisis.

\section{REFERENCES}

Ajlan, S. and Al-Ajlan. 2012. A Comparative Study Between E-Learning Features, Methodologies, Tools and New Developments for E-Learning, Dr. Elvis Pontes (Ed.), ISBN: 978-953-51-0029-4, InTech, Available from: http:// www.intechopen.com/books/methodologies-tools-andnew-developments-for-e-learning/a-comparativestudybetween-e-learning-features

Bolliger, D.U. and Martindale, T. 2004. Key factors for determining student satisfaction in online courses. International Journal on E-Learning, 3(1): 61-67.

Capper, J. 2001. The emerging market for online learning: insights from the corporate sector, European Journal of Education, 36(2): 237- 245.

Easton, S.S. 2003. Clarifying the instructor's role in online distance learning. Communication Education, 52(2): 87-105.

Ellis, R.K. 2009. Field Guide to Learning Management Systems. Learning Circuits, pp. 1-3.

https://ethinkeducation.com/blog/building-a-modern-virtuallearning-environment-vle/

BBC News. 2020. Coronavirus pandemic: Tracking the global outbreak, 25 July, 2020.

UNESCO. 2020. COVID-19 Educational Disruption and Response. https://en.unesco.org/covid19/ educationresponse. Retrieved Feb 2020.

https://scand.com/company/blog/the-use-of-virtual-learningenvironment-in-education/

https://www.futurereadyedu.com/virtual-learningenvironments-vles/

Kelly, P. and Roberts, L. 2000. Challenges for university administrators in the online world, Perspectives, 4(4): 95- 99. 
Laeeq, K. and Memon, Z.A. 2018. An integrated model to enhance virtual learning environments with current social networking perspective. International Journal of Emerging Technologies in Learning (iJET), 13(09): 252-268.

Lee, J. 2010. Online support service quality, online learning acceptance, and student satisfaction. Internet and Higher Education, 13: 277-283.

Mansoori, S. and Shorif, N. 2019. Impact of social networking sites on academic performance of post-graduate students of aligarh muslim university. Journal of Emerging Technologies and Innovative Research (JETIR), 6(4): 320- 329.

McAvinia, C. 2016. Online learning and its users: lessons for higher education. Retrieved from https://ebookcentral. proquest.com

Roblyer, M.D., McDaniel, M., Webb, M., Herman, J. and Witty, J.V. 2010. "Findings on Facebook in higher education: A comparison of college faculty and student uses and perceptions of social networking sites", Internet and Higher Education, 13: 134-140.
Shakique, M. and Mansoori, S. 2017. A Study of web 2.0 Technologies in Teaching- Learning Process. International Journal of Education and Psychological Research (IJEPR), 6(3): 50- 54.

Trafford, P. and Shirota, Y. 2011. An Introduction to Virtual Learning Environments, Gakushuin Economics Pap., 48(10): 143- 151.

Volery, T. and Lord, D. 2000. Critical Success Factors in Online Education. International Journal of Educational Management, 14(5): 216.

Weller, M. 2007. Virtual learning environments: using, choosing and developing your VLE. Abingdon: Routledge.

Westbrook, V. 2006. The virtual learning future, Teaching in Higher Education, 11(4): 471- 482. 
